\title{
Tüketicilerin Kişilik Özellikleri ile Finansal İyilik Hâli ve Risk Alma Tutumu Arasındaki İlişki ${ }^{1}$
}

\section{The Relationship Between Personality Characteristics of Consumers with Financial Well-Being and Risk-Taking Attitude}

\author{
A.Selçuk KÖYL $\ddot{U} O \breve{G} L U^{*}$ \\ Abdurrahman GÜMRAH** \\ Mesut DOG $\breve{G} A N^{* * *}$
}

\begin{abstract}
$\ddot{O} Z$
Bu çalışmanın amacı, tüketicilerin kişilik özellikleri ile finansal iyilik hali ve risk alma tutumu arasındaki ilişkiyi incelemektir. Ayrıca tüketicilerin demografik özelliklerine göre kişilik özellikleri ile finansal iyilik hali ve risk alma tutumunun farklılaşıp farklılaşmadı̆̆ da tespit edilmiştir. Bu amaçla araştırmada Selçuk Üniversitesi'nde öğrenim gören 200 ögrenci üzerinde bir anket uygulaması gerçekleştirilmiştir. Çallşmada kişilik özellikleri (Five Factor), finansal iyilik hali ve risk alma tutumu ölçekleri kullanılmıştır. Yapılan analizler sonucunda öğrencilerin cinsiyete göre risk alma tutumu ve finansal iyilik hali ortalamalarının istatistiksel olarak anlamlı bir şekilde farklılaştı̆̆ tespit edilmiştir. Başka bir ifade ile erkek ögrencilerin, kız ögrencilere göre risk alma tutumu algısl ve finansal iyilik hali alglsl daha yüksektir. Buna karşın katılımcıların cinsiyetine göre beş faktör kişilik envanteri farklılaşmamaktadır. Ayrıca risk alma tutumu algısı açısından deneyime açıklık, uzlaşabilirlik, dışa dönüklük boyutları ile pozitif ve güçlü bir ilişki, buna karşın nevrotiklik ile negatif bir ilişki tespit edilmiştir. Finansal iyilik hali bakımından deneyime açıklık, uzlaşabilirlik, öz disiplin boyutları ile pozitif ve güçlü bir ilişki buna karşın nevrotiklik boyutu ile negatif ilişskiye ulaşılmıştır.
\end{abstract}

\section{ANAHTAR KELIMELER}

Kişilik Özellikleri, Finansal Iyilik Hali, Risk Alma Tutumu

\begin{abstract}
The aim of this study is to investigate the relationship between the personal characteristics of consumers and their financial well-being and risk-taking attitudes. In addition, it has been determined whether the personality characteristics, financial well-being and risk taking attitudes differ according to the demographic characteristics of the consumers. For this purpose, a questionnaire was applied to 200 students studying at Selcuk University. Five factors, financial well-being and risk taking attitude scales were used in the study. As a result of the analyzes, it was determined that the average risk taking attitude and financial well-being of the students differed statistically according to gender. In other words, male students have higher risk perception and financial well-being than female students. However, the five-factor personality inventory does not differ according to the gender of the participants. In addition, a positive and strong relationship with perception of risk taking attitude, openness to experience, reconciliation and extroversion, but a negative relationship with neuroticism was determined. There is a positive and strong relationship with financial well-being, openness to experience, reconciliation and self-discipline, whereas a negative relationship with neuroticism.
\end{abstract}

\section{KEYWORDS}

Personality Characteristics, Financial Goodness, Risk-Taking Attitude

\begin{tabular}{|c|c|c|}
\hline \multicolumn{2}{|c|}{ Makale Geliş Tarihi / Submission Date } & \multicolumn{1}{c|}{$\begin{array}{c}\text { Makale Kabul Tarihi / Date of Acceptance } \\
26.11 .2019\end{array}$} \\
\hline \multirow{4}{*}{ Atıf } & $\begin{array}{l}\text { Köylüoğlu, A.S., Gümrah, A. ve Doğan, M. (2019). Tüketicilerin Kişilik Özellikleri ile Finansal İyilik Hâli ve Risk } \\
\text { Alma Tutumu Arasındaki İlişki.. Selçuk Üniversitesi Sosyal Bilimler Meslek Yüksekokulu Dergisi, 22 (2), 903-913. }\end{array}$ \\
\hline
\end{tabular}

\footnotetext{
${ }^{1}$ Bu çalışma 28-30 Haziran 2019 tarihlerinde KKTC'de düzenlenen 3.Uluslararası EMI Girişimcilik ve Sosyal Bilimler Kongresinde sözlü bildiri olarak sunulmuş, çalışmanın özeti kongre özet kitapçığında yayınlanmıştır.

* Dr. Öğr. Üyesi, Selçuk Üniversitesi, Kulu Meslek Yüksekokulu, Dış Ticaret Programı, askoyluoglu @ selcuk.edu.tr, ORCID:0000-0003-0359-1443

*** Dr. Öğr. Üyesi, Selçuk Üniversitesi, Sosyal Bilimler Meslek Yüksekokulu, Lojistik Programı, agumrah@selcuk.edu.tr, ORCID: 0000-0003-2588-7448

*** Doç. Dr., Afyon Kocatepe Üniversitesi, Bayat Meslek Yüksekokulu, İşletme Bölümü, mesutdogan07@gmail.com,

ORCID: 0000-0001-6789-1361
} 


\section{GİRIŞ}

Her bireye özgü bir kavram olan kişilik, doğuştan gelen özellikler ve çevresel koşullar ile şekil kazanmaktadır. Kişiliğin oluşumunda etkisi olan bu çoğulculuk, gelişim örüntüsünün farklılık arz etmesi neticesini ortaya koymaktadır. İnsanlar sahip oldukları değer yargıları, fiziksel görünüşleri ve kognitif yetenekleri açısından birbirine benzemedikleri gibi sergiledikleri davranış açısından da birbirine benzememektedirler. İnsanları birbirinden farklı kılan bu özellikler bir araya geldiğinde ise kişilik oluşmaktadır (İstanbul Işsletme Enstitüsü, 25.06.2019). Kişilik kavramının pazarlama açısından da önemi bilinmektedir ancak bu konuya dair yapılan araştırmalarda çıkan sonuçlar arasında bir mutabakat söz konusu değildir. Zira bazı çalışmalar, kişiliği pazarlamanın çeşitli temel kavramlarıyla ilişkilendirirken kimi çalışmalarda böylesi bir ilişkinin olmadığı ileri sürülmektedir. Oysa, tüketici araştırmaları ve pazarlama bilimi birbirini tamamlayan bir bütün olmakla birlikte insan davranışlarıyla da yakından ilgilidir ve 1970' li yıllarda yapılan tanımlamalarda tüketicilere yönelik içsel ve dışsal etmenler göz önüne alınmıştır. Örneğin tüketici davranışında kültürel geçmiş, sosyal sınıf gibi dış etmenlerin yanında algı, kişilik ve tutum gibi iç etmenler de etkilidir (Shoaf, Scattone, Morrin \& Maheswaran, 1995). Kişilik ve pazarlama bilimi arasındaki bağ, "bana tükettiğini söyle sana kim olduğunu söyleyeyim” türünden sembolize edilecek kadar güçlüdür (Odabaşı \& Barış, 2014). Bu itibarla, bugünün pazarlama literatüründe kişilik, çevresel uyarıcılara uygun karş1lık verme şeklinde kabul görmektedir. Kişilik aynı zamanda, kişisel ya da toplumsal birden fazla etkenin kümülatif etkileşiminin tüketici davranışını etkileyen bir çıktısı olarak da değerlendirilmektedir (Tenekecioğlu, 2009).

Bu bağlamda bugünün pazarlama mantalitesinin en büyük kazanımı, tüketici memnuniyetinin sağlanması adına yapılan tüketici araştırmalarıyla tüketici özelliklerine iddialı bir şekilde hâkim olmaktır. Güncel bir metodoloji olan disiplinlerarası yaklaşım, yakaladığı ivmeyi bu gerekçeye borçludur. Öyle ki, pazarlamanın tüketicilerin kişilik özellikleriyle ilgilenmesi, psikoloji bilimiyle dirsek temasında olduğunun bir göstergesidir. Benzer şekilde tüketicilerin yatırım, harcama ve borç gibi risk içeren durumlarda, risk/getiri tercihlerinde hangi özelliklerinin ön plana çıktığının bilinmesi de pazarlamanın finans alanıyla olan ilintisinin bir ispatıdır. Pazarlamada olduğu gibi finans alanının da merkezinde insan vardır ve yatırımcıların algıları, tutumları ve kişilik özellikleri pazarlamayı da ilgilendirmektedir. Zira uluslararası rekabetin giderek kızıştığı finans dünyasında artık yatırımcıların sahip olduğu bireysel özelliklerinin de incelenmesi önem ihtiva etmektedir (Kahneman\&Riepe, 1998). Davranışsal ekonomi olarak zikredilen ve literatürdeki yerini kabul ettiren bu yaklaşım, geleneksel modelin tersi bir fonksiyona sahiptir ve psikolojinin bu alanda ne kadar ihmal edildiğini vurgulamaktadır. Yani insanların iç dünyalarının göz ardı edildiği ya da bir kenara bırakıldığı değil, bilakis, pazar reaksiyonlarının \%90' ının psikolojiye, sadece geriye kalan \%10’ luk kısmın gerçeklere yaslandığını ileri sürmektedir (Tigges, v.d., 2000).

$\mathrm{Bu}$ doğrultuda, disiplinlerarası bir yaklaşımla pazarlamanın psikoloji ve finans alanlarıyla işbirliği üzerine inşa edilen bu çalışmada amaç, tüketicilerin kişilik özelliklerini finansal iyilik hâli ve risk alma tutumu ile ilişkilendirmektir. Kişiliğin oluşumu pek çok etkene bağımlı olduğundan, depresif ve hüzünlü, mesafeli, enerji dolu, gergin, tembelliğe meyilli, girişken gibi çok çeşitli kişilik özelliklerinden bahsetmek mümkündür. Bu özellikler pazarda belirleyici role sahip olduğundan pazarlama ve psikoloji arasındaki ilişki bu bakış açısına dayanarak kurulmuştur. Bunun için Goldberg (1993)' in geliştirdiği Beş Faktör Kişilik Modeli kullanılmıştır (John\&Srivastava, 1999). Bazı insanların finansal davranışlarda çok endişeli olmaları ve bazılarının da daha az duyarlı olmaları finansal iyilik hâlini göstermektedir (Strömbäck, v.d., 2017). Finansal iyilik bir bakıma kişinin kendini güvenli bir limanda hissetmesidir. Tüketicilerin borçlanmaları finansal iyilik hâllerini etkilemekte, finansal olaylara karşı tutumları da borçlanmalarını etkilemektedir. Finansal açıdan risk algılamalarına etki eden faktörlerin bilinmesi ise, harcama-tasarruf ve buna benzer diğer pek çok eşleştirmede finansal risk ve firsatların daha iyi görülmesini sağlamaktadır ve bu bakış açısı da pazarlamanın finansla olan ilişkisini göstermektedir. Finansal iyilik hâlinin ölçümünde Norvilitis, Szablicki, ve Wilson (2003) tarafindan geliştirilen ölçeğe başvurulurken, risk alma tutumunun ölçülmesinde Sjöberg ve Engelberg (2009) tarafindan geliştirilen ölçekten yararlanılmıştır. Çalışma giriş bölümünün akabinde üç bölümden oluşmaktadır. İlk bölümde kişilik ve özellikleri, finansal iyilik hâli ve risk alma tutumu gibi temel kavramlara yer verilmiştir. İkinci bölümde literatürde konuyla ilgili yapılmış çalışmalar taranmıştır. Üçüncü bölüm yöntem ve bulguların yer aldığı çalışmanın metodolojisidir. Yöntem ve eldeki bulgularla ulaşılan çıktılar sonuç kısmında değerlendirilmiştir.

\section{KAVRAMSAL ÇERÇEVE}

1930’ lu yıllarda kişilik psikolojisinin sosyal bilimler alanlarından ayrı düşünülmeye başlamasıyla ortaya çıkan bir bilimsel disiplin olan kişilik kavramıyla ilgili literatürde birçok tanım mevcuttur. Ryckman (2008), kişiliği sosyal çekicilik olarak tanımlamıştır. Butler (1986), insanların dış dünyada yüzlerine taktıkları maske 
olarak nitelendirmiştir. McCrae ve Costa (1989), kişiliğin bir etkileşim tarzı olduğunu ifade etmiş ve farklı zamanlarda sergilenen sürekliliği olan, duygusal, kişilerarası, tecrübe edilen bir değer olarak nitelendirmiştir. Burger (2006), münferit kaynakların tutarlı davranış kalıpları ve içsel süreçleri şeklinde izah etmiştir (Horzum, Ayaş\&Padır, 2017). Terimin birçok tanımına rağmen, araştırmacılar genellikle kişiliğin çeşitli durumlarda bir kişinin bilişlerini, motivasyonlarını ve davranışlarını benzersiz şekilde etkileyen, sahip olduğu dinamik ve organize özellikler kümesi olduğu konusunda hemfikirdir (Ryckman, 2008). Kişiliğin gelişiminde birçok faktörün etkisinin olması, bu konu üzerinde çalışma yapan pek çok araştırmacının çeşitli kuram ve modeller geliştirmesinin önünü açmıştır. Freud-Psikoanalitik Kuram, Jung-Analitik Psikoloji, Adler-Bireysel Psikoloji, Horney-Sosyal ve Kültürel Psikanaliz, Erikson-Psikoanalitik Ego Psikolojisi, Skinner-Edimsel Analiz, KohutBenlik Psikolojisi, Allport-Kişilik Özellikleri Kuramı, Rogers-Kendini Gerçekleştirme Kuramı, Cattell-Yapı Temelli Sistemler Kuramı, Eysenck-Biyolojik Tipoloji, Rotter-Beklenti Değer Kuramı, Bandura-Sosyal Bilişsel Kuramlar iken, Myers-Briggs Tipi Kișilik Modeli, Beş Faktör Kişilik Modeli, FIRO-B Kişilik Değerlendirme Modeli, Katherine Benziger' in Beyin Tipi Teorisi, Belbin Takımı Rolleri ve Kişilik Tipleri Teorisi de kişilik modellerinden bazılarıdır. (Ryckman, 2008).

$\mathrm{Bu}$ doğrultuda, kişiliği açıklamak üzere yapılan nicel çalışmalarla, özellikleri bakımından kişiliğin beş güçlü faktör çerçevesinde düzenlenebileceği idrak edilmiştir. Yaklaşık 2000 yılından bu yana, bu çalışmada da başvurulan beş faktör yaklaşımı, kişilik alanındaki araştırmaların temel taşı olarak değer görmektedir (McCrae\&Costa, 1987; Goldberg, 1990; Camgöz, 2009). Beş faktör kişilik özellikleri modeli iki ayrı uçtan meydana gelmiş, kapsamında beş ayrı kişilik boyutu yer almaktadır (McCrae\&John, 1992; Camgöz, 2009). $\mathrm{Bu}$ alt boyutlar dışa dönüklük-içe dönüklük, uyumluluk-uyumsuzluk/düşmanlık, sorumluluk-dürtüsellik, nevrotiklik-duygusal denge ve deneyime açıklık-gelenekçilik şeklindedir. Dışa dönüklük; sosyal, girişkenlik, enerjik, maceracı, coşkulu, samimi olarak, içe dönüklük ise; çekingen, utangaç ve sıkılgan olarak tanımlanmaktadır (Barrick\&Mount, 1991). Nazik olmak, merhametli olmak, saygin olmak uyumluluk boyutunda yer alırken, uyumsuzluk boyutunda huysuzluk, hırçınlık, şüphecilik yer almaktadır (Somer, 1998). Öz disiplin; çalışkan, güvenilir, disiplinli, dakik, düzenli olmayı gerektirirken, dürtüsellik; dağınık, düzensiz, güvenilmez ve dikkatsiz olmayı gerektirmektedir. Nevrotiklik; endişeli, sinirli, duygusal, güvensiz, olarak; duygusal denge de; sakin, özgüveni tam şeklinde nitelendirilmektedir (Şenyuva, 2007). Son olarak deneyime açıklık boyutunda meraklı, kreatif, hayal gücü geniş, sayısal düşünebilen özellikleri yer alırken, gelenekçilik boyutu tam tersi bir fonksiyona sahiptir ve sığ bir düşünce potansiyeline sahip, sade ve kurallara bağlı bir yaşam biçimi gibi özellikler sergilemektedir (Camgöz, 2009).

Temel dinamiği toplumun her zaman daha fazla tüketmesine dayalı olarak işlerlik gösteren tüketim ekonomisi, internet gibi alış veriş yapılabilecek mecraların da artış göstermesiyle tüketicileri her an sahip oldukları paradan daha fazlasını harcamaya sevk etmektedir. Finansal enstrümanların çeşitlenmesinin önünü açan bu evolüsyon, tüketicinin finansal açıdan güvenli bir liman olarak algıladığı finansal iyilik kavramını doğurmuştur. Zimmerman (1995), iyiliği, sağlıklı, mutlu ve özgür olmanın bir hali olarak tanımlamaktadır. Finansal iyilik ise, kişinin kendini finansal açıdan güven içinde algılaması şeklinde tanımlanabilir (Sunal, 2012). Ekonomik veya finansal iyilik olarak da adlandırılan bu kavram, bireyin finansal yaşamını geniş bir yelpazede ele almaktadır (Joo, 2008). Williams (1993), finansal iyiliğin, kişinin finansal durumunun maddi ve maddi olmayan yönlerinin bir işlevi olduğunu ortaya koymaktadır. Finansal iyilik para, gerçek gelir, psişik gelir veya algılanan gelir yeterliliği gibi konuları içermektedir $($ Joo, 2008). Bunun yanı sıra finansal iyilik, fiziksel ve mental sağlık, akademik başarı ve yaşamdan duyulan genel tatminle de ilişkilidir. Dolayısıyla finansal iyilik, kişilerin finansal memnuniyetleri ya da memnuniyetsizlikleri, onların fiziksel ve zihinsel sağlıkları, yaşamdan duydukları haz ve psikolojik uyumları gibi pek çok faktörden etkilenmektedir (Schoeni\&Ross, 2005). Çalışmanın konusunun bir bölümü olan tüketicilerin kişilik özellikleri ve finansal iyilik hâli arasındaki ilişkinin dayanak noktası burasıdır.

Çalışmanın bir diğer bölümünü ise tüketicilerin kişilik özellikleri ile risk alma tutumu arasındaki ilişki oluşturmaktadır. Tüketici davranışını etkileyen önemli bir faktör olan kişiliğin yanı sıra risk alma tutumu da tüketici davranışı üzerinde ciddi bir etkiye sahiptir. Zira tüketiciler farklı kişilik özelliklerine sahip olduklarından benzer bir ürünü elde etmek için katlanılacak riske karşı farklı tutum sergileyebilmektedirler. Fransızca "risque" ve İtalyanca "risicare", kelimelerinde türeyen ve TDK (Türk Dil Kurumu)' da zarara uğrama tehlikesi olarak açıklanan risk, Wikipedia' da, ölçülemeyen, kontrol edilemeyen ve tahmin edilemeyen bir sonuca rağmen karar alma neticesi şeklinde tarif edilmiştir (Wikipedia, 01.07.2019). Bir başka tanımda, yaşanan olaylar karşısında o olayla ilgili tehlike etkisini tecrübe etme ihtimali olarak tanımlanmaktadır (Short, 1984). Kısaca, risk, bireyin içsel ve dışsal süreçlerini olumsuz etkileyebilecek faktörlerin bir bütünüdür (Trimpop, 1994). Araştırmalarda kullanılan risk türleri performans riski, finansal risk, zaman riski, fiziksel risk, sosyal risk ve psikolojik risktir. Konuyla bağlantısı yönünden finansal risk, bir ürünün para harcamaya 
değer olmadığı şeklinde açıklanmaktadır (Evans\&Berman, 1997). Riskle ilgili yapılan pek çok tanım beraberinde iktisat, psikoloji ve istatistik gibi farklı disiplinlerde riskin daha ziyade kazanma ve kaybetme olasılıkları üzerinde durulmuştur. Pazarlama bilim dalının önemli bir konusu olan tüketici davranışlarında ise, riskin yalnız tüketiciler üzerindeki olumsuz davranışları üzerinde durulmuştur (Dholakia, 2001). Bu açıdan risk, tüketicilerin ürüne gereğinden fazla ödeme yapmaları ile ilgilidir (Kinnear, v.d., 1995). Tüketicilerin pazarlama faaliyetlerine yönelik olumsuz veya şüpheci tutumları, riskin tutum üzerindeki etkisinden hareketle risk alma tutumu kavramını ortaya çıkarmıştır. Risk alma tutumu, genel olarak kişinin içsel ve dışsal süreçlerini etkilediğinden çok yönlü bir davranış biçimidir. Gonzales \&Tiffany, (1994), hem kişinin yaşamı açısından hem de sosyal ilişkileri açısından olumsuzlukla sonuçlanabilecek davranışlar olarak tanımlamaktadır. Bir başka tanımda ise, kayıplar ve kazançlar ile dengelenmiş davranışlar olarak nitelendirilmektedir (Moore\&Gullone, 1996). Tüketicilerin risk alma tutumu kişiye, ürüne, duruma vb. pek çok faktöre göre değiştiğinden, çalışmada kişilik özellikleri ile risk alma tutumu arasındaki ilişki bu çıkış noktasından hareketle kurgulanmıştır.

\section{LITERATÜR}

Çalışma literatürü, konu gereği kişilik özellikleri ile finansal iyilik ve risk alma tutumu arasındaki ilişki olmak üzere iki kısımda ele alınmıştır.

Davies ve Lea (1995), üniversite öğrencilerinin aşırı borçlanmalarının finansal iyilik hâlini olumsuz etkilediğini bildirmiştir. Sullivan (2012) ve Ross, v.d., (2006), yüksek miktardaki borçlanmaların öğrencilerde yarattığı stres kaynağının kişisel bozukluklara neden olduğu ve bunun finansal iyilik hâlini olumsuz etkilediğini tespit etmişlerdir. Borçlu öğrencilerin kaygı düzeylerinin yüksek olmasının kuvvetle muhtemel olduğu da benzer çalışmalarda ortaya konulmuştur (Roberts v.d., 1998; Stradling, 2001). Kolayca sahip olunabilen bir ödeme aracı olan kredi kartları aynı zamanda harcamaların da artmasına neden olmaktadır. Borç maliyetini artıran söz konusu durum, özellikle gençlerde finansal iyilik hâline negatif tesiri olmaktadır. (Shim, v.d., 2009). Bruggen v.d., (2017), Grable ve Joo (2004) ve Malone v.d., (2010), finansal iyi olma hâlini yaş, cinsiyet, eğitim durumu, aile yapısı gibi değişkenlerin yanında kişisel özelliklerin de etkilediğini savunmuşlardır. Kişilerin uzun vadede borç yükü gibi kötü finansal şartlarla yüz yüze gelmeleri finansal iyilik hâlini olumsuz etkilemektedir (Adams \& Moore, 2007). Conger, Rueter \& Conger (2000), finansal iyiliğin, kişilerin psikolojik ve fiziksel sağlıkları ve yaşamdan duydukları tatmin ile ilgili olduğunu savunmuşlardır. Norvilitis, v.d., (2003), finansal iyilik hali ölçeğini geliştirmiştir. Bu ölçeğe göre, bireylerin finansal iyilik hâli açısından kendilerini ne şekilde değerlendirdikleri ölçülebilmektedir.

Nicholson, v.d., (2005), risk alma tutumunu aç1klarken beklenti teorisine vurgu yapmıştır. Risk davranışlarının bireyler arasında ciddi oranda farklılıklar gösterdiğini belirtmiştir. Çalışmada bireyler heyecan arayanlar, kayıptan kaçınanlar ve riski uyarlayanlar olmak üzere üç boyutta ele alınmıştır. Fenton O' Creevy, Nicholson, Soane ve Willamn (2005), kişilik özelliklerinin etraflıca ele alındığı çalışmada, risk alma tutumunu da incelemişlerdir. Sonuç olarak, duygusal dengesi yüksek, içe dönük ve deneyime açık olan bireylerin daha yüksek finansal performansa sahip oldukları ortaya çıkmıştır. Staw ve Barsade (1993), pozitif duygulara sahip oldukları için dışa dönük kişilerin daha doğru karar verme yeteneklerinin olduğunu ortaya koymuştur. Eysenck (1985)' e göre, dışa dönük bireyler, tehlikeli durumlara girmekten çekinmeyen, soğukkanlı, girişken ve hızlı karar verebilen kimselerdir (Karancl, Dirik, Yorulmaz, 2007). Saraç ve Kahyaoğlu (2011) ve Erdem (2001), diğer faktörler beraberinde kişilik özelliklerinin de risk alma eğilimi üzerinde etkisinin olduğunu bildirmişlerdir. Mayfield v.d., (2008), cinsiyet ile riskten kaçınma arasında ilişki aradıkları çalışmalarında anlamlı ilişki bulamazken, kadınların erkeklere nazaran riskten uzak durduklarını tespit etmişlerdir. Dohmen v.d., (2005), araştırmalarını örneklem olarak Almanya' da yaşayan yaklaşık 22.000 kişi üzerinde uygulamışlardır. Araştırma sonucunda bütün yaş grubu itibariyle kadınların erkeklere kıyasla daha az risk üstlenmeye meyilli oldukları tespit edilmiştir. Sitkin ve Pablo (1992), çalışmalarında insanların bilerek risk aldıklarını ortaya koymuşlardır. Bunun gerekçesini de riskten beklenen kısmi faydaya dayandırmaktadırlar. Kişilik özelliklerine ailenin de etkisi olduğu anlayışından hareketle, finansal yatırımla ilgisi olan ailelerin çocuklarının da yatırımlarını erken yaşlarda yaptıkları tespit edilmiştir. (Research Department Investment Company Institute, 1993). Kimlik kazanma süreciyle ilgilenmeyen dağınık kimlik statüsündeki bireylerin risk alma tutumlarına başvurma eğilimleri daha yüksektir (Marcia, 1980). Kaplan, v.d., (1974), tüketicilerin satın alma esnasında finansal, psikolojik, sosyal, performans ve fiziksel olmak üzere beş tür risk algıladıklarını bildirmiştir. Tüketicilerin bir işi gönüllü yapmaları ile yapmamaları arasında da risk alma eğilimi açısından farklılıklar mevzu bahistir. Gönüllü faaliyetlerde daha az risk algısı söz konusu iken, isteksiz faaliyetlerde daha çok risk algısı söz konusudur (Mowen\&Minor, 2001). 


\section{METODOLOJI}

Çalışmanın bu kısmında araştırmanın metodolojisine ilişkin bilgilere yer almaktadır. Aşağıda ilk olarak araştırmanın amacı ve önemi belirtilmiştir. Akabinde araştırmada kullanılan yöntem ve kapsam üzerinde durulmuş ve son olarak da araştırmanın kısıtlarına yer verilmiştir.

\subsection{Araştırmanın Amacı ve Önemi}

Bu çalışmanın temel amacı, tüketicilerin kişilik özellikleri ile finansal iyilik hali ve risk alma tutumları arasındaki ilişkiyi incelemektir. Söz konusu temel amaç yanında, çalışmada ayrıca tüketicilerin demografik özelliklerine göre finansal iyilik hali ve risk alma tutumlarının farklılaşıp farklılaşmadığının tespit edilmesi de çalışmanın alt amacını oluşturmaktadır. Yapılan literatür taraması sonucunda, tüketicilerin kişilik özellikleri ile finansal iyilik halleri ve risk alma tutumları arasındaki ilişkinin aynı anda incelendiği bir araştırmaya rastlanamamıştır. Bu açıdan çalışma sonucunda ulaşılan bulgularla literatüre katkı yapılacağı düşünülmektedir. Bu durum çalışmanın önemini daha da arttırmaktadır.

\subsection{Araştırmanın Yöntemi ve Kapsamı}

Araştırmada yüz yüze görüşme tekniği kullanılarak anket yöntemi uygulanmıştır. Uygulanan anket formları dört ana bölümden oluşmaktadır. Birinci bölümde katılımcıların demografik özelliklerini tespit etmeye yönelik 10 ifade, ikinci bölümde katılımcıların kişilik özelliklerini tespit etmeye yönelik 44 ifade, üçüncü bölümde finansal iyilik halinin tespit edilmesine yönelik 10 ifade ve anket formunun son kısmını oluşturan dördüncü bölümde katılımcıların risk alma tutumlarını tespit etmeye yönelik 22 ifade yer almaktadır. Katılımcıların kişilik özelliklerini ölçmek amacıyla John ve Srivastava (1999); John, Naumann\&Soto (2008) tarafından geliştirilen "The Big Five Inventory" ölçeği kullanılmıştır. "The Big Five Inventory” ölçeği, dışadönüklük boyutu ( 8 ifade), uyumluluk boyutu ( 9 ifade), özdisiplin boyutu (9 ifade), nevrotiklik boyutu ( 8 ifade), deneyime açıklık boyutu (10 ifade) olmak üzere beş boyuttan oluşmaktadır. Risk alma tutumu için Sjöberg ve Engelberg (2009) tarafindan geliştirilmiş ve Uçar (2014) tarafından Türkçe' ye uyarlanmış ölçekten yararlanılmıştır. Son olarak bireysel finansal özgüven ve finansal mutluluk duygularını ölçmek amacıyla Norvilitis, Szablicki ve Wilson (2003) tarafından geliştirilen finansal iyilik ölçeği kullanılmıştır. Araştırmada kullanılan tüm ölçeklerde $0.80^{\prime}$ in üzerinde yüksek güvenirlilik tespit edilmiştir.

Katılımcılara demografik özellikleri tespit etmeye yönelik olanlar hariç diğer ifadelerde 5' li likert ölçeği şeklinde katılımcıların cevap vermeleri istenmiştir. Çalışmanın kapsamı üniversite öğrencileri ile sınırlı tutulmuştur. $\mathrm{Bu}$ bağlamda Selçuk Üniversitesi'nin farklı birimlerinde öğrenci olan 200 öğrenci araştırma kapsamına alınmıştır. Türkiye'de mevcut tüm üniversite öğrencilerinin araştırma kapsamına alınmak istemesinin zaman, maliyet ve fiziki imkânsızlıklarından ötürü araştırmanın kapsamı Türkiye'nin köklü ve öğrenci sayısı olarak en büyük üniversitelerinden birisi olan Selçuk Üniversitesi ile sınırlı tutulmuştur.

Araştırmada elde edilen veriler SPSS 25.0 programı yardımı ile analiz edilmiştir. Ampirik analizlerde güvenirlilik analizleri ve normallik testleri uygulanmıştır. Araştırmada kullanılan tüm ölçeklerin normal dağılmasından dolayı t-testi ve pearson korelasyon yöntemlerinden yararlanılmıştır.

\subsection{Bulgular}

Çalışmanın bu kısmında araştırma kapsamında yapılan uygulama sonucunda ulaşılan bulgulara yer verilmiştir.

Tablo 1: Katılımcıların Demografik Bilgileri

\begin{tabular}{|l|l|l|l|}
\hline & Değişkenler & N & \% \\
\hline \multirow{2}{*}{ cinsiyet } & Kadın & 108 & 54,0 \\
\cline { 2 - 4 } & Erkek & 92 & 46,0 \\
\hline \multirow{2}{*}{$\begin{array}{l}\text { Girişimcilik Dersi Aldınız } \\
\text { mı? }\end{array}$} & Evet & 50 & 25,0 \\
\cline { 2 - 4 } & Hayır & 150 & 75,0 \\
\hline \multirow{2}{*}{$\begin{array}{l}\text { Üniversiteden mezun } \\
\text { olduktan sonra ne } \\
\text { yapacaksınız? }\end{array}$} & İmkan bulursam kendi işimi kurmak isterim & 104 & 52,0 \\
\cline { 2 - 4 } & $\begin{array}{l}\text { Kamu ya da özel sektörde ücretli çalışmak } \\
\text { isterim }\end{array}$ & 96 & 48,0 \\
\hline \multirow{3}{*}{ Babanızın İ̧̧i } & Kendi işinde çalışmakta & 97 & 48,5 \\
\cline { 2 - 4 } & $\begin{array}{l}\text { Ücretli olarak kamu ya da özel sektörde } \\
\text { çalışmakta }\end{array}$ & 103 & 51,5 \\
\hline
\end{tabular}


Tablo 1' de katılımcıların demografik bilgilerine yer verilmiştir. Tablo 1' de görüldüğü üzere araştırmaya katılan katılımcılardan 108 kişisi kadın, 92 kişisi ise erkektir. Kadın katılımcılar araştırmaya katılanların \%54' lük kısmını oluştururken, erkek katılımcılar \%46' lık kısmı oluşturmaktadır. Ayrıca araştırmaya katılan öğrencilerin yaklaşık yarısı imkân bulursa kendi işini kurmak istediği ve babaları ücretli olarak kamu ya da özel sektörde çalıştığı anlaşılmaktadır. Son olarak öğrencilerin \% 075 ' i girişimcilik dersi almamıştır.

Tablo 2: Katılımcıların Cinsiyete Göre Risk Alma Tutumunun, Finansal İyilik Hâlinin ve Kişilik Özelliklerinin Karşılaştırılması

\begin{tabular}{|c|c|c|c|c|c|c|}
\hline Ölçekler & Gruplar & $\mathbf{N}$ & $\overline{\mathbf{x}}$ & Ss & $\mathbf{T}$ & P \\
\hline \multirow{2}{*}{ Risk Alma Tutumu } & Kadın & 108 & 3,3981 & ,71899 & \multirow{2}{*}{2,793} & \multirow{2}{*}{0,006} \\
\hline & Erkek & 92 & 3,1472 & ,51463 & & \\
\hline \multirow{2}{*}{ Finansal İyilik Hâli } & Kadın & 108 & 3,0815 & 80549 & \multirow{2}{*}{2,06} & \multirow{2}{*}{0,041} \\
\hline & Erkek & 92 & 2,8598 & ,69977 & & \\
\hline \multicolumn{7}{|c|}{ Beş Faktör Kişilik Envanteri } \\
\hline \multirow{2}{*}{ Dışa Dönüklük } & Kadın & 108 & 3,4016 & ,58357 & \multirow{2}{*}{0,295} & \multirow{2}{*}{0,768} \\
\hline & Erkek & 92 & 3,3777 & ,55624 & & \\
\hline \multirow{2}{*}{ Uzlaşılabilirlik } & Kadın & 108 & 3,2106 & ,52050 & \multirow{2}{*}{1,184} & \multirow{2}{*}{0,238} \\
\hline & Erkek & 92 & 3,1209 &, 55018 & & \\
\hline \multirow{2}{*}{ Öz Disiplin } & Kadın & 108 & 3,3621 & ,69586 & \multirow{2}{*}{1,786} & \multirow{2}{*}{0,076} \\
\hline & Erkek & 92 & 3,2065 &, 50087 & & \\
\hline \multirow{2}{*}{ Nevrotiklik } & Kadın & 108 & 3,2049 & ,55257 & \multirow{2}{*}{1,309} & \multirow{2}{*}{0,192} \\
\hline & Erkek & 92 & 3,1101 & ,45575 & & \\
\hline \multirow{2}{*}{ Deneyime Açılıı } & Kadın & 108 & 3,4315 & ,56298 & \multirow{2}{*}{0,877} & \multirow{2}{*}{0,382} \\
\hline & Erkek & 92 & 3,3620 &, 55447 & & \\
\hline
\end{tabular}

Tablo 2' de katılımcıların cinsiyete göre risk alma tutumu, finansal iyilik hâli ve kişilik özellikleri t-testi ile karşılaş̧ırılmıştır. Analiz sonuçları incelendiğinde öğrencilerin cinsiyete göre risk alma tutumu ve finansal iyilik hâli ortalamalarının istatistiksel olarak anlamlı bir şekilde farklılaştığı anlaşılmaktadır $(p<0,05)$. Başka bir ifade ile erkek öğrencilerin, kız öğrencilere göre risk alma tutumu algısı ve finansal iyilik hâli algısı daha yüksektir. Buna karşın katılımcıların cinsiyete göre beş faktör kişilik envanteri farklılaşmamaktadır ( $\mathrm{p}>0,05)$.

Tablo 3: Katılımcıların Girişimcilik Dersi Alma Durumuna Göre Risk Alma Tutumunun, Finansal İyilik Hâlinin ve Kişilik Özelliklerinin Karşılaştırılması

\begin{tabular}{|c|c|c|c|c|c|c|}
\hline Ölçekler & Gruplar & $N$ & $\overline{\mathbf{x}}$ & Ss & $\mathbf{T}$ & P \\
\hline \multirow{2}{*}{ Risk Alma Tutumu } & Evet & 50 & 3,3391 &, 82215 & \multirow{2}{*}{0,714} & \multirow{2}{*}{0,476} \\
\hline & Hayır & 150 & 3,2639 &, 57469 & & \\
\hline \multirow{2}{*}{ Finansal İyilik Hâli } & Evet & 50 & 3,1440 & ,87182 & \multirow{2}{*}{1,765} & \multirow{2}{*}{0,079} \\
\hline & Hayır & 150 & 2,9247 & ,72064 & & \\
\hline \multicolumn{7}{|c|}{ Beş Faktör Kişilik Envanteri } \\
\hline \multirow{2}{*}{ Dışa Dönüklük } & Evet & 50 & 3,5275 &, 56935 & \multirow{2}{*}{1,975} & \multirow{2}{*}{0,05} \\
\hline & Hayır & 150 & 3,3450 &, 56456 & & \\
\hline \multirow{2}{*}{ Uzlaşılabilirlik } & Evet & 50 & 3,2625 & ,62793 & \multirow{2}{*}{1,425} & \multirow{2}{*}{0,156} \\
\hline & Hayır & 150 & 3,1383 & 49856 & & \\
\hline \multirow{2}{*}{ Öz Disiplin } & Evet & 50 & 3,4733 & ,85914 & \multirow{2}{*}{$-2,447$} & \multirow{2}{*}{0,015} \\
\hline & Hayır & 150 & 3,2296 &, 50133 & & \\
\hline \multirow{2}{*}{ Nevrotiklik } & Evet & 50 & 3,2600 & ,66425 & \multirow{2}{*}{$-1,583$} & \multirow{2}{*}{0,115} \\
\hline & Hayır & 150 & 3,1283 & ,44683 & & \\
\hline \multirow{2}{*}{ Deneyime Açıklık } & Evet & 0 & 5360 & 7985 & \multirow{2}{*}{2,01} & \multirow{2}{*}{, 046} \\
\hline & Hayır & 50 & 3540 & 4596 & & \\
\hline
\end{tabular}


Tablo 3' te katılımcıların girişimcilik dersi alma durumuna göre risk alma tutumu, finansal iyilik hali ve kişilik özellikleri t-testi ile karşılaştırılmıştır. Analiz sonuçları incelendiğinde öğrencilerin girişimcilik dersi alma durumuna göre risk alma tutumu ve finansal iyilik hâli ortalamalarının istatistiksel olarak anlamlı bir şekilde farklılaşmadığı görülmektedir ( $\mathrm{p}>0,05)$. Başka bir ifade ile girişimcilik dersi alan ve girişimcilik dersi almayan öğrencilerin risk alma tutumu algısı ve finansal iyilik hâli algısı birbiri ile eştir. Benzer bir şekilde katılımcıların girişimcilik dersi alma durumuna göre beş faktör kişilik envanteri "uzlaşılabilirlik" ve "nevrotiklik" boyutları farklılaşmamaktadır $(\mathrm{p}>0,05)$. Buna karşın "dışa dönüklük", "öz disiplin" ve "deneyime açıklık" boyutları girişimcilik dersi alma durumuna göre değişmektedir $(p<0,05)$. Yani, girişimcilik dersi alan öğrencilerin girişimcilik dersi almayan öğrencilere göre "dışa dönüklük", "öz disiplin" ve "deneyime açıklık" gibi kişilik özellikleri daha yüksektir.

Tablo 4: Katılımcıların Mezun Olduktan Sonra Yapacakları İşe Göre Risk Alma Tutumunun, Finansal İyilik Hâlinin ve Kişilik Özelliklerinin Karşılaştırılması

\begin{tabular}{|c|c|c|c|c|c|c|}
\hline Ölçekler & Gruplar & $\mathbf{N}$ & $\overline{\mathbf{x}}$ & Ss & $\mathbf{T}$ & $\mathbf{P}$ \\
\hline \multirow{2}{*}{ Risk Alma Tutumu } & İmkân bulursam kendi işimi kurmak isterim & 104 & 3,3505 & 62651 & \multirow{2}{*}{1,555} & \multirow{2}{*}{0,122} \\
\hline & Kamu ya da özel sektörde ücretli çalışmak isterim & 96 & 3,2093 & 65789 & & \\
\hline \multirow{2}{*}{ Finansal İyilik Hali } & İmkân bulursam kendi işimi kurmak isterim & 104 & 2,9740 & ,71706 & \multirow{2}{*}{$-0,105$} & \multirow{2}{*}{0,917} \\
\hline & Kamu ya da özel sektörde ücretli çalışmak isterim & 96 & 2,9854 & ,81731 & & \\
\hline \multicolumn{7}{|c|}{ Beş Faktör Kişilik Envanteri } \\
\hline \multirow{2}{*}{ Dışa Dönüklük } & İmkân bulursam kendi işimi kurmak isterim & 104 & 3,4591 &, 57042 & \multirow{2}{*}{$-1,779$} & \multirow{2}{*}{0,077} \\
\hline & Kamu ya da özel sektörde ücretli çalışmak isterim & 96 & 3,3164 &, 56282 & & \\
\hline \multirow{2}{*}{ Uzlaşılabilirlik } & İmkân bulursam kendi işimi kurmak isterim & 104 & 3,1815 &, 54968 & \multirow{2}{*}{$-0,333$} & \multirow{2}{*}{0,74} \\
\hline & Kamu ya da özel sektörde ücretli çalışmak isterim & 96 & 3,1563 &, 52094 & & \\
\hline \multirow{2}{*}{ Öz Disiplin } & İmkân bulursam kendi işimi kurmak isterim & 104 & 3,3504 &, 71352 & \multirow{2}{*}{1,431} & \multirow{2}{*}{0,154} \\
\hline & Kamu ya da özel sektörde ücretli çalışmak isterim & 96 & 3,2257 & ,48805 & & \\
\hline \multirow{2}{*}{ Nevrotiklik } & İmkân bulursam kendi işimi kurmak isterim & 104 & 3,2019 &, 53128 & \multirow{2}{*}{1,172} & \multirow{2}{*}{0,243} \\
\hline & Kamu ya da özel sektörde ücretli çalışmak isterim & 96 & 3,1172 & ,48761 & & \\
\hline \multirow{2}{*}{ Deneyime Açıklık } & İmkân bulursam kendi işimi kurmak isterim & 104 & 3,4452 &, 56840 & \multirow{2}{*}{1,205} & \multirow{2}{*}{0,23} \\
\hline & Kamu ya da özel sektörde ücretli çalışmak isterim & 96 & 3,3500 &, 54676 & & \\
\hline
\end{tabular}

Tablo 4' te katılımcıların mezun olduktan sonra yapacakları işe göre risk alma tutumu, finansal iyilik hâli ve kişilik özellikleri t-testi ile karşılaştırılmıştır. Analiz sonuçları incelendiğinde öğrencilerin mezun olduktan sonra yapacakları işe göre risk alma tutumu, finansal iyilik hâli ve kişilik envanteri ortalamalarının istatistiksel olarak anlamlı bir şekilde farklılaşmadığ kurmak isteyenler ile ücretli olarak çalışmak isteyenlerin risk alma tutumu algısı, finansal iyilik hâli algısı ve kişilik özellikleri birbiri ile benzerdir. 
Tablo 5: Öğrenci Babalarının İşine Göre Risk Alma Tutumunun, Finansal İyilik Hâlinin ve Kişilik Özelliklerinin Karşılaştırılması

\begin{tabular}{|c|c|c|c|c|c|c|}
\hline Ölçekler & Gruplar & $\mathbf{N}$ & $\overline{\mathbf{x}}$ & Ss & $T$ & $\mathbf{P}$ \\
\hline \multirow[b]{2}{*}{ Risk Alma Tutumu } & Kendi işini yapmakta. & 97 & 3,2573 & ,74735 & \multirow[b]{2}{*}{$-0,542$} & \multirow[b]{2}{*}{0,589} \\
\hline & $\begin{array}{l}\text { Kamu ya da özel sektörde } \\
\text { ücretli çalışmakta. }\end{array}$ & 103 & 3,3067 & 53137 & & \\
\hline \multirow[b]{2}{*}{ Finansal İyilik Hali } & Kendi işini yapmakta. & 97 & 2,9876 &, 77194 & \multirow[b]{2}{*}{0,145} & \multirow[b]{2}{*}{0,884} \\
\hline & $\begin{array}{l}\text { Kamu ya da özel sektörde } \\
\text { ücretli çalışmakta. }\end{array}$ & 103 & 2,9718 & ,76189 & & \\
\hline \multicolumn{7}{|c|}{ Beş Faktör Kişilik Envanteri } \\
\hline \multirow[b]{2}{*}{ Dışa Dönüklük } & Kendi işini yapmakta. & 97 & 3,3814 & 61724 & \multirow[b]{2}{*}{$-0,221$} & \multirow[b]{2}{*}{0,826} \\
\hline & $\begin{array}{l}\text { Kamu ya da özel sektörde } \\
\text { ücretli çalışmakta. }\end{array}$ & 103 & 3,3993 & 52425 & & \\
\hline \multirow[b]{2}{*}{ Uzlaşılabilirlik } & Kendi işini yapmakta. & 97 & 3,1662 & 56213 & \multirow[b]{2}{*}{$-0,08$} & \multirow[b]{2}{*}{0,936} \\
\hline & $\begin{array}{l}\text { Kamu ya da özel sektörde } \\
\text { ücretli çalışmakta. }\end{array}$ & 103 & 3,1723 &, 51065 & & \\
\hline \multirow[b]{2}{*}{ Öz Disiplin } & Kendi işini yapmakta. & 97 & 3,2864 &, 77825 & \multirow[b]{2}{*}{$-0,093$} & \multirow[b]{2}{*}{0,926} \\
\hline & $\begin{array}{l}\text { Kamu ya da özel sektörde } \\
\text { ücretli çalışmakta. }\end{array}$ & 103 & 3,2945 & ,41653 & & \\
\hline \multirow[b]{2}{*}{ Nevrotiklik } & Kendi işini yapmakta. & 97 & 3,2075 &, 57985 & \multirow[b]{2}{*}{1,242} & \multirow[b]{2}{*}{0,216} \\
\hline & $\begin{array}{l}\text { Kamu ya da özel sektörde } \\
\text { ücretli çalışmakta. }\end{array}$ & 103 & 3,1177 & ,43542 & & \\
\hline & Kendi işini yapmakta. & 97 & 3,4165 & 56175 & \multirow[b]{2}{*}{0,417} & \multirow[b]{2}{*}{0,677} \\
\hline Deneyime Açıklık & $\begin{array}{l}\text { Kamu ya da özel sektörde } \\
\text { ücretli çalışmakta. }\end{array}$ & 103 & 3,3835 &, 55820 & & \\
\hline
\end{tabular}

Tablo 5' te öğrenci babalarının işine göre risk alma tutumu, finansal iyilik hâli ve kişilik özellikleri t-testi ile karşılaştırılmıştır. Analiz sonuçları incelendiğinde öğrencilerin öğrenci babalarının işine göre risk alma tutumu, finansal iyilik hâli ve kişilik envanteri ortalamalarının istatistiksel olarak anlamlı bir şekilde farklılaşmadığı anlaşılmaktadır $(p>0,05)$. Şu şekilde de ifade edilebilir ki, babası kendi işinde çalışanlar ve ücretli olarak çalışanların risk alma tutumu algısı, finansal iyilik hâli algısı ve kişilik özellikleri birbiri ile benzerdir.

Tablo 6: Kişilik Özellikleri ile Risk Alma Tutumu ve Finansal İyilik Hali Arasındaki İlişki

\begin{tabular}{|l|l|l|}
\hline & Risk Alma Tutumu & Finansal İyilik Hâli \\
\hline Risk Alma Tutumu & 1 &, $177^{*}$ \\
\hline Finansal İyilik Hâli &, $177^{*}$ & 1 \\
\hline Dışa Dönüklük &, $202^{* *}$ &, $148^{*}$ \\
\hline Uzlaşılabilirlik &, $200^{* *}$ &, $230^{* *}$ \\
\hline Öz Disiplin &, $175^{*}$ &, $229^{* *}$ \\
\hline Nevrotiklik &,$- 300^{* *}$ &,$- 194^{* *}$ \\
\hline Deneyime Açıklık &, $258^{* *}$ &, $215^{* *}$ \\
\hline
\end{tabular}

Tablo 6' da kişilik özellikleri ile risk alma tutumu ve finansal iyilik hâli arasındaki ilişki pearson korelasyon analizi ile test edilmiştir. Analiz sonuçları incelendiğinde risk alma tutumu algısı açısından deneyime açıklık, uzlaşabilirlik, dışa dönüklük boyutları ile pozitif ve güçlü bir ilişki, buna karşın nevrotiklik ile negatif bir ilişki tespit edilmiştir. Finansal iyilik hâli bakımından deneyime açıklık, uzlaşabilirlik, öz disiplin boyutları ile pozitif ve güçlü bir ilişki buna karşın nevrotiklik boyutu ile negatif ilişkiye ulaşılmıştır.

\section{SONUÇ}

Bu araştırmada tüketicilerin kişilik özellikleri ile finansal iyilik hâli ve risk alma tutumları arasındaki ilişki incelenmiştir. Çalışmada ayrıca tüketicilerin demografik özelliklerine göre kişilik özellikleri, finansal iyilik hâli ve risk alma tutumlarının farklılaşıp farklılaşmadığ 1 tespit edilmiştir. Bu amaç doğrultusunda Selçuk Üniversitesinde öğrenim gören 200 öğrenci üzerinde bir anket uygulaması gerçekleştirilmiştir. Çalışmada kişilik özellikleri (Five Factor), finansal iyilik hâli ve risk alma tutumu ölçekleri kullanılmıştır. Araştırmada elde edilen veriler SPSS 25.0 programı yardımı ile analiz edilmiştir. Ampirik analizlerde güvenirlilik analizleri 
ve normallik testleri uygulanmıştır. Araştırmada kullanılan tüm ölçeklerin normal dağılmasından dolayı t-testi ve pearson korelasyon yöntemlerinden yararlanılmıştır.

Yapılan analizler sonucunda öğrencilerin cinsiyete göre risk alma tutumu ve finansal iyilik hâli ortalamalarının istatistiksel olarak anlamlı şekilde farklılaştı̆̆ tespit edilmiştir. Yani erkek öğrencilerin kız öğrencilere göre risk alma tutumu algısı ve finansal iyilik hâli algısı daha yüksektir. Buna karşın katılımcıların cinsiyete göre beş faktör kişilik envanteri farklılaşmamaktadır. Ayrıca "dışa dönüklük", "öz disiplin" ve "deneyime açıklık" boyutlarının girişimcilik dersi alma durumuna göre farklılaştığı belirlenmiştir. Girişimcilik dersi alan öğrencilerin girişimcilik dersi almayan öğrencilere kıyasla "dışa dönüklük", "öz disiplin" ve "deneyime açıklık" kişilik özellikleri daha yüksek çıkmıştır. Bununla birlikte öğrencilerin mezun olduktan sonra yapacakları işe ve babalarının işine göre risk alma tutumları, finansal iyilik hâli ve kişilik envanteri ortalamalarının istatistiksel olarak anlamlı bir şekilde farklılaşmadığı görülmüştür. Buradan hareketle, öğrencilerin mezun olduktan sonra yapmak istedikleri iş ve babalarının mesleğinin risk alma tutumunda, finansal iyilik hâlinde ve kişilik envanterinde çok da etkisinin olmadığı şeklinde bir yorum yapılabilir.

Araştırmada tespit edilen bir diğer önemli bulgu ise, risk alma tutumu algısı perspektifinden deneyime açıklık, uzlaşabilirlik ve dışa dönüklük boyutları ile pozitif ve güçlü bir ilişkinin varlığı dikkat çekmiştir. Diğer taraftan risk alma tutumu algısı ile nevrotiklik boyutu arasında da negatif yani olumsuz bir ilişki söz konusudur. Ortaya çıan bu ilişki göstermektedir ki, deneyim kazanmak isteyen, insancıl ilişkilerde daha sıcak-samimi ve çevresiyle iletişim halinde olan bireylerin risk alma tutumları daha yüksektir. Ama bunun tam tersi davranış sergileyen -sinirsellik gibi- bireylerin risk almadıkları ya da daha az risk üstlendikleri anlaşılmaktadır. Finansal iyilik hâli bakımından ise, deneyime açıklık, uzlaşabilirlik, öz disiplin boyutları ile pozitif ve güçlü bir ilişkiye erişilmiş ancak nevrotiklik boyutu ile negatif ilişkiye ulaşılmıştır. Bu da demek oluyor ki, tecrübe kazanmaya hevesli, daha yapıcı, sosyal yönü yüksek ve disipline edilmiş bir yaşamı tercih eden bireylerin finansal iyilik hâlleri yüksektir. Ama agresif, içine kapanık, insancıl ilişkileri zayıf ve öz disiplini düşük bir yaşam süren bireylerin finansal iyilik halleri de düşüktür.

Sosyal bilimler alanında yapılan tüm bilimsel çalışmalarda olduğu gibi bu çalışmanın da bir takım kısıtları mevcuttur. Öncelikle, araştırmanın Türkiye' de bulunan tüm üniversite öğrencilerine yönelik yapılması aşırı kaynak, maliyet ve zaman külfeti yüklemektedir. Bu kısıt dolayısıyla araştırma kapsamına Selçuk Üniversitesinde okuyan 200 öğrenci alınmıştır. Bu açıdan, araştırma neticesinde ortaya çıkan sonuçlar araştırmanın yapıldığı üniversiteyi bağlamaktadır. Dolayısıyla tüm üniversite öğrencilerini genelleyecek şekilde yorumlanması yanlış sonuçlar doğurabilecektir. Zira araştırmada uygulanan anket formlarının farklı üniversitelerde ve farklı sayılarda öğrenci üzerine uygulanması farklı sonuçlar ortaya çıkarabilecektir. Bundan sonra buna benzer yapılacak çalışmalarda, üniversite sayılarının ve öğrenci sayılarının artırılıp çalışmanın daha farklı üniversitelerde ve daha fazla sayıdaki öğrenci üzerinde yürütülmesi daha sağlıklı sonuçlar alınması adına önerilebilir. 


\section{KAYNAKÇA}

Adams, T., Moore, M. (2007). High-Risk Health And Credit Behavior Among 18- To 25 Year-Old College Students, Journal of American College Health, 56(2), 101-108.

Barrick, M.R. \& Mount, M.K. (1991). "The big five personality dimensions and job performance. A meta analysis", The Personnel Psychology, 44, 1-26.

Bruggen , E., Hogreve, J., Holmlu, M., Kabadayi, S., Löfgren, M. (2017). Financial well-being: a conceptualization and research agenda. Journal of Business Research, 79, 228-237.

Butler, W.E. (1986). Personality, http://www.hermetics.org/kisilik.html, 27.06.2019.

Camgöz, S. M. (2009). "Kişilik Özelliklerinin A- Tipi Fon Yöneticilerinin Seçicilik ve Zamanlama Becerileri Üzerine Etkileri", İktisat İşletme ve Finans, 24(284), 109-141.

Conger, K. J., Rueter, M. A., Conger, R. D, (2000), The Role of Economic Pressure in the Lives of Parents and Their Adolescents: The Family Stress Model, Child Developmental, 65 (2), 541 - 561.

Davies, E., Lea, S.E.G. (1995) “Student Attitudes to Atudent Debt” Journal of Economic Psychology, 16, 663 - 679.

Dholakia, U. (2001). A motivational process model of product involvement and consumer risk perception. European Journal of marketing, 35(11/12), 1340-1362.

Dohmen, Thomas, Armin Falk, David Huffman, Uwe Sunde, Jürgen Schupp ve Gert G.Wagner (2005). "Individual Risk Attitudes: New Evidence from a Large, Representative, Experimentally-Validated Survey”, IZA Discussion Paper, No. 1730, September.

Erdem, F. (2001). Girişimcilerde risk alma eğilimi ve belirsizliğe tolerans ilişkisine kültürel yaklaşım. Akdeniz University Faculty of Economics \& Administrative Sciences Faculty Journal/Akdeniz Universitesi Iktisadi ve Idari Bilimler Fakultesi Dergisi, 1(2), 43-61.

Evans, J.R., Berman, B. (1997). Marketing, 7th. Edition, Prentice Hall International.

Fenton O' Creevy, M., Nicholson, N., Soane, E., \& Willamn, P. (2005). Traders, managing risks and decisions financial markets, Oxford University Press, USA.

Goldberg, L. R. (1990). An alternative ""Description of Personality": The Big-Five factor structure", Journal of Personality and Social Psychology, 59(6), 1216-1229.

Gonzales, J., \& Tiffany, F. (1994). Adolescents perceptions of their risk taking behavior. Adolescence, 29(13), $701-711$.

Grable , J. E., Joo, S. (2004). Environmental and biophysical factors associated with financial risk tolerancex. Journal of Financial Counseling and Planning, 15(1), 73-82.

Horzum, M. B., Ayas, T. \& Padır, M. A. (2017). "Beş Faktör Kişilik Ölçeğinin Türk Kültürüne Uyarlanması”, Sakarya University Journal of Education, 7(2), 398-408.

https://www.iienstitu.com/blog/kisilik-nedir, (25.06.2019)

https://tr.wikipedia.org/wiki/Risk, (01.07.2019).

John, O. P., \& Srivastava, S. (1999). The Big-Five trait taxonomy: History, measurement, and theoretical perspectives. In L. A. Pervin \& O. P. John (Eds.), Handbook of personality: Theory and research, 2,102-138.

Joo, S. (2008). "Personal Financial Wellness", Handbook of Consumer Finance Research. Kahneman, D., \& Riepe, M. (1998). "Aspects of inventor psychology", Jornal of Portfolio Management, 24, 52-67.

Kaplan, L. B., Szybillo, G. J., ve Jacoby, J. (1974), “Compenents of Perceived Risk inProduct Purchase: a CrossValidation” , Journal of Applied Psychology, 59(3), 287-291.

Karancı, A. N., Dirik, G., Yorulmaz, O. (2007). Eysenck Kişilik Anketi -Gözden Geçirilmiş Kısaltılmış Formunun (EKAGGK) Türkçe Adaptasyonu, Türk Psikiyatri Dergisi, 18(3), 1-8.

Kinnear, T.G., Berhhart, K.L., Krentler, K. A. (1995). Principles of Marketing, 4th. Edition, Harper Collins College Puplishers.

Malone, K., Stewart, S., Wilson, J., Korschi, P. (2010). Perceptions of financial well-being among American women in diverse families. Journal of Family and Economic Issues, 31(1), 63-81.

Marcia, J. E. (1980). Identity in adolescence. In J. Adelson (Ed.).Handbook of adolescent psychology, New York: Wiley, $159-187$.

Mayfield C., Perdue G., Wooten K., (2008), “Investment Management and Personality Type”, Financial Services Review, 17 (3), 219-236.

McCrae, R.R., Costa, P.T. (1987). "Validation of the five-factor model across instruments and observers", Journal of Personality and Social Psychology, 52, 81-90.

McCrae, R.R., Costa, P.T. (1989). "Reinterpreting the Myers-Briggs type indicator fromthe perspective of the five-factor model of personality", Journal of Personality, 57, 17-40.

McCrae, R. R., \& John, O. P. (1992). "An introduction to the five factor model and its applications", Journal of Personality, 60, 175-215.

Moore, S., \& Gullone, E. (1996). Predicting adolescent riskbehavior using a personalized cost benefit analysis. Journal of Youth andAdolescence, 25(11), 343-359.

Mowen, J.C., Minor, M.S. (2001). Consumer Behaviour: A Framework, Prentice-Hall, 1st Ed., United States of America.

Nicholson N., Soane E., Fenton-O'Creevy M., Willman P., (2005), "Personality and Domain-Specific Risk Taking”, Journal of Risk Research, 8(2), 157-176. 
Norvilitis, J. M., Szablicki, P. B., \& Wilson, S. D. (2003). Factors influencing levels of credit-card debt in college students. Journal of Applied Social Psychology, 33(5), 935-947.

Odabaşı, Y. ve Barış, G. (2014). Tüketici Davranışı, 14. Baskı, İstanbul: MediaCat Yayınları.

Research Department Investment Company Institute (1993), "Piecing Together Shareholder Perceptions of Investment Risk", 1-61.

Roberts, R., Golding, J., and Towell, T. (1998) "Student Finance and Mental Health" The Psychologist, 489-491.

Ross, S. C., Macleod, M.J. (2006) "Stress, Debt and Undergraduate Medical Student Performance” Medical Education, 40(6), 584-589.

Ryckman, R. M. (2008). Theories of Personality (9. Edition). California: Thomson Wadsworth.

Saraç, M., Kahyaoğlu, M. (2011). Bireysel yatırımcıların risk alma eğilimine etki eden sosyo-ekonomik ve demografik faktörlerin analizi. Journal of BRSA Banking \& Financial Markets,, 5(2), 135 - 157.

Schoeni, R.F., \& Ross, K. E, (2005). "Material Assistance from Families during the Transition to Adulthood”, University of Chicago Press, Chicago, 396-416.

Shim, S., v.d., (2009). Pathways to life success: A conceptual model of financial well-being foryoung adults. Journal of Applied Developmental Psychology, 30(6), 708-723.

Shoaf, F.R., Scattone, J., Morrin, M. \& Maheswaran, D. (1995). "Gender Differences in Adolescent Compulsive Consumption", Advances in Consumer Research, 22, 500-504.

Short, J. (1984). The social fabric at risk: Toward the social transformation of risk analysis. American Sociological Review, 49(6), 711-725.

Sitkin S. B., Pablo A. L., (1992), "Reconceptualizing the determinants of risk behavior", Academy of Management Review, 17 (1), 9-38.

Sjöberg L., Engelberg E. (2009). "Attitudes to economic risk taking, sensation seeking and values of business students specializing in finance", Journal of Behavioral Finance, 10 (1), 33- 43.

Somer, O. (1998). “Türkçe' de kişilik özelliği tanımlayan sıfatların yapısı ve beş faktör modeli”, Türk Psikolojisi Dergisi, $13,17-32$.

Staw, B., \& Barsade, S. (1993). Affect and managerial performance: A test of the sadder- but-wiser vs. happier and smarter hypotheses, Administrative Science Quarterly, 38, 304-331.

Stradling, S. (2001) “The Psychological Effects of Student Debt” Scott, A. Lewis and S. Lea (eds.) Student Debt: The Causes and Consequences of Undergraduate Borrowing in the UK, Bristol, The Policy Press.

Strömbäck, C., Lind, T., Skagerlund, K., Västfjäll, D. and Tinghög, G. (2017). Does self-control predict financial behavior and financial well-being?. Journal of Behavioral and Experimental Finance, 14, 30-38.

Sullivan, M. S. (2012), A Study of The Relationship Between Personality Types and The Acceptance of Technical Knowledge Management Systems (Tkms), (Doctor of Philosophy, Capella University), 1-149.

Sunal, O. (2012). "Finansal İyilik Hali Ölçeği (FİHÖ): Geçerlik ve Güvenirlik Çalışması", Ege Akademik Bakış, 12(2), 209-214.

Şenyuva, H.Şenay (2007). “Aydın İlinden Alınan Normal Bir Örneklemde Kişilik Bozukluklarının Yaygınlık Çalışması”, (Psikiyatri Uzmanlık Tezi), Adnan Menderes Üniveristesi, Sağlık Bilimleri Enstitüsü, Aydın.

Tenekecioğlu, B. (2009). Pazarlama Yönetimi, 7. Baskı, Eskişehir: Anadolu Üniversitesi web-Ofset Tesisleri.

Tigges, P., Riegert, A., Jonitz, L., Brengelman, J. \& Engel, R. (2000). "East bhavior of East and West Germans in handling personal finances", Journal of Psychology and Financial Markets, 1(2), 127-134.

Trimpop, R.M. (1994). The psychology of risk taking behavior. Amsterdam: Elsevier.

Zimmerman, S. L. (1995). "Understanding family policy: Theories and applications", (second ed.). Thousand Oaks, CA: Sage. 